\title{
PENGARUH MODEL PEMBELAJARAN BERBASIS PORTOFOLIO DAN KEMAMPUAN AWAL TERHADAP HASIL BELAJAR PENDIDIKAN KEWARGANEGARAAN
}

\author{
Rohani $^{1}$ dan Abdul Hamid K. ${ }^{2}$ \\ Madrasah Aliyah Laboratorium IAIN SU Medan1 dan Universitas Negeri Medan ${ }^{2}$ \\ rohani@gmail.com ${ }^{l}$
}

\begin{abstract}
Abstrak: Penelitian ini bertujuan untuk mengetahui: perbedaan hasil belajar pendidikan kewarganegaraan siswa yang diberi model pembelajaran portofolio dengan kelompok siswa yang diberi model pembelajaran konvensional, perbedaan hasil belajar pendidikan kewarganegaraan antara siswa yang memiliki kemampuan awal tinggi dengan kemampuan awal rendah, dan interaksi antara model pembelajaran dengan kemampuan awal dalam mempengaruhi hasil belajar pendidikan kewarganegaraan. Metode adalah kuasi eksperimen dengan rancangan factorial $2 \times 2$. Teknik analisis data yang digunakan adalah ANAVA dua jalur. Hasil penelitian menunjukkan: Model Pembelajaran berbasis portofolio memberikan hasil belajar PKn siswa lebih tinggi dibandingkan dengan model pembelajaran konvensional, diperoleh $F_{\text {hitung }}=9,275>F_{\text {tabel }}=4,013$. Kelompok siswa yang kemampuan awalnya tinggi memperoleh skor hasil belajar PKn yang lebih tinggi di banding dengan kelompok siswa yang kemampuan awalnya rendah diperoleh $F_{\text {hitung }} 7,310$ $>F_{\text {tabel }}=4,013$. Terdapat interaksi antara model pembelajaran dengan kemampuan awal dalam mempengaruhi hasil belajar PKn siswa diperoleh $F_{\text {hitung }}=7,479>F_{\text {tabel }}=2,761$.
\end{abstract}

Kata Kunci: model pembelajaran berbasis portofolio, kemampuan awal, pendidikan kewarganegaraan

\begin{abstract}
This study aims to determine: differences in learning outcomes civic education of students who were learning model portfolio with a group of students who were given conventional learning models, differences in learning outcomes of civic education among students who have prior knowledge high initial ability is low, and the interaction between learning model with early ability in influencing civic education learning outcomes. The method is a quasi-experimental design with a $2 \times 2$ factorial. Data analysis technique used was ANOVA two lanes. The results showed: Model-based learning portfolio Civics student learning outcomes is higher than the conventional learning models, obtained $F c=9.275>F t=4.013$. The group initially high ability students who obtain a score of learning outcomes Civics higher compared with group initially low ability students who obtained $F c 7.310>F t=4.013$. There is interaction between the learning model with early ability in influencing student learning outcomes Civics obtained $F c=7.479>F t$ $=2.761$.
\end{abstract}

Keywords: portfolio-based learning model, beginning ability, civic education

\section{PENDAHULUAN}

Proses pembelajaran yang berkualitas membutuhkan guru sebagai pengelola dan mengembangkan pembelajaran yang inovatif, yakni pembelajaran yang memiliki gagasan, ide untuk memunculkan strategi, metode atau teknik sebagai cara yang tepat diformulasikan untuk mencapai proses pembelajaran yang efektif. Sebagai seorang perancang dalam pembelajaran, guru sangat berperan dalam menentukan berhasil tidaknya pencapaian tujuan pembelajaran. Agar tujuan pembelajaran dapat tercapai, guru dituntut untuk memiliki keterampilan mengajar dan dapat mengorganisasikan bahan pelajaran sedemikian rupa sehingga pembelajaran menjadi menarik.

Pada saat ini terdapat kecenderungan bahwa guru sering menggunakan teknik-teknik pembelajaran yang tidak memobilisasi siswa dalam upaya menumbuh kembangkan cara berpikir siswa atau bersikap serta mempunyai keterampilan yang memadai, sehingga siswa kurang merasa bebas berekspresi, ini dapat dilihat dari hasil yang diperolehnya, baik dari sikapnya ataupun dari perilakunya. Soemantri (2001) mengemukakan bahwa digunakannya 
teknik-teknik pembelajaran seperti itu disebabkan oleh beberapa faktor yaitu, kebiasan teknik pembelajaran yang sudah melembaga sejak dulu dan teknik pembelajaran tersebut adalah yang paling mudah dilakukan.

Dengan penurunan nilai dari tahun ajaran sebelummya membuktikan bahwa dalam mata pelajaran pendidikan kewarganegaraan perlu dikaji lebih mendalam lagi, mengapa hal ini dapat terjadi di Madrasah Aliyah Laboratorium. Selain itu bila dilihat dari aspek non akademik, banyak kritik terhadap masalah kedisiplinan, moral dan etika, kreativitas, kemandirian, dan sikap demokratis yang tidak mencerminkan tingkat kualitas yang diharapkan oleh masyarakat luas (Sidi, 2001). Hal ini menjadi tantangan bagi guru pendidikan kewarganegaraan dalam upaya untuk lebih meningkatnya hasil yang lebih optimal baik nilai maupun tingkah laku. Pemberdayaan nilainilai etika dan moral siswa bukan suatu hal yang mudah dilakukan.

Pembelajaran berbasis portofolio (portfolio based learning) mengupayakan berbagai keterampilan kepada siswa, terutama yang berkaitan dengan kepekaan dalam menemukan dan menentukan permasalahan yang mendesak untuk segera dipecahkan, merumuskan format permasalahan, menentukan berbagai sumber yang diperkirakan dapat membantu memecahkan permasalahan, melatih melakukan pengumpulan data atau informasi terhadap berbagai sumber yang berhubungan dengan kebijakan publik, merumuskan format laporan hasil pengumpulan data, dan menyajikan portofolio yang berisi upaya pemecahan masalah-masalah kemasyarakatan.

Sardiman (2003) mengartikan belajar sebagai kegiatan psiko-fisik menuju ke perkembangan pribadi seutuhnya. Selanjutnya menurut Skinner dalam belajar akan ditemukan hal-hal sebagai berikut : (1) kesempatan terjadinya peristiwa-peristiwa belajar, (2) respon orang yang belajar (3) konsekuensi yang bersifat menggunakan respon tersebut, baik konsekuensi sebagai hadiah maupun teguran atau hukuman.

Belajar juga merupakan suatu proses penambahan tingkah laku sebagai suatu hasil interaksi dengan lingkungannya dalam memenuhi kebutuhannya dengan ciri-ciri : (1) perubahan terjadi secara sadar, (2) perubahan dalam belajar terjadi bersifat kontinu dan fungsional, (3) perubahan dalam belajar bersifat positif dan aktif artinya perubahan itu senantiasa bertambah dan tertuju untuk memperoleh sesuatu yang lebih baik dari sebelumnya, (4) perubahan dalam belajar bukan bersifat sementara tetapi bersifat permanen, (5) perubahan dalam belajar bertujuan dan terarah, (6) perubahan dalam belajar mencakup seluruh aspek tingkah laku (Slamento, 1995). Senada dengan pendapat tersebut, Fudyartanto (2002) menjelaskan bahwa ciri-ciri perubahan tingkah laku dalam belajar sebagai berikut: (a) belajar adalah perubahan dalam diri seorang yang dinyatakan dalam kecakapan suatu sikap, (b) belajar adalah penguasaan pola-pola perilaku baru, (c) belajar adalah penguasaan kecakapan, sikap, dan pengertian dalam belajar yang sesungguhnya. Dari pengertian tersebut dapat dipahami dengan belajar manusia menperoleh perubahan tingkah laku dalam bentuk suatu kecakapan ataupun kepandaian.

Dari uraian tentang pengertian belajar, dapat dikemukakan bahwa melalui belajar manusia mengalami perubahan-perubahan dalam kebiasaan, kecakapan yang berkaitan pada aspek pengetahuan, sikap, dan keterampilan. Dengan demikian, belajar merupakan aktivitas mental yang membawa perubahan relatif permanen dan diperoleh melalui pengalaman.

Pendapat tersebut dikemukakan Hamalik (2003) yang mengemukakan bahwa belajar merupakan perubahan tingkah laku yang relatif mantap berkat latihan dan pengalaman. Definisi belajar yang dikemukakan oleh Hamalik mengandung pengertian bahwa dalam belajar harus dilakukan dengan sengaja, direncanakan sebelumnya dengan struktur tertentu dan membentuk tingkah laku yang baru. Sejalan dengan pendapat tersebut, Daradjat (2002) menyatakan bahwa belajar adalah suatu bentuk perubahan dalam diri seseorang yang dinyatakan dengan cara-cara bertingkah laku yang baru berkat pengalaman dan latihan. Dalam hal ini belajar senantiasa merupakan kegiatan yang berlangsung di dalam suatu proses dan terarah kepada pencapaian suatu tujuan tertentu dan menghasilkan perubahan tingkah laku. Perubahan tingkah laku tersebut dilakukan secara kebetulan.

Pendidikan kewarganegaraan yang berhasil akan membuahkan sikap mental yang disertai dengan perilaku; 1) beriman dan bertakwa kepada Tuhan Yang Maha Esa dan menghayati nilai-nilai falsafah bangsa; 2) berbudi pekerti luhur, berdisiplin dalam bermasyarakat, berbangsa, dan bernegara; 3) rasional, dinamis, dan sadar akan hak dan kewajiban sebagai warga negara; 4) bersifat 
profesional yang dijiwai oleh kesadaran bela negara (Sumarsono dkk, 2002). Berdasarkan penjelasan tersebut, pada hakikatnya pendidikan kewarganegaraan merupakan pendidikan yang mengenali dan menghayati hak-hak asasi warga negara, yang perlindungannya dijamin oleh undang-undang negara serta dapat membangkitkan empati pada diri siswa dimana kesadaran bahwa orang lain sebagai sesama warga atau sesama manusia adalah penyandang hak yang sama yang harus pula dihormati.

Berdasarkan pendapat-pendapat tersebut, mata pelajaran pendidikan kewarganegaraan secara substansi terdiri atas seperangkat pengetahuan yang diluapkan, dimiliki, dihayati, dan ditampilkan dalam berbagai perilaku bersifat moral dan pengetahuan. Menurut Soemantri (2001) substansi mata pelajaran pendidikan kewarganegaraan terdiri atas moral pancasila dan pengetahuan kewarganegaraan, kedua substansi ini berhubungan erat dengan pendidikan politik, hukum, dan nilai, karena pada dasarnya unsur-unsur dan jenis pendidikan tersebut merupakan suatu rumpun pendidikan dalam kehidupan bermasyarakat dan bernegara.

Untuk menjabarkan substansi mata pelajaran pendidikan kewarganegaraan di atas Menurut Soemantri (2001), tujuan pembelajaran pendidikan kewarga negaraan dalam prakteknya harus dijabarkan dalam tujuan kurikuler yang meliputi: (1) ilmu pengetahuan yang meliputi hierarki, fakta, konsep, dan generalisasi, (2) keterampilan intelektual : yang meliputi keterampilan yang kompleks, dari penyelidikan sampai kesimpulan yang sahih, dan dari berpikir kritis ke berpikir kreatif; (3) sikap yang meliputi nilai kepekaan, dan perasaan; (4) keterampilan sosial; yang meliputi keterampilan yang memberikan kemungkinan kepada siswa untuk dapat melakukan, bersikap cerdas, dan bersahabat dalam pergaulan hidup sehari-hari.

Dengan melihat penjabaran tujuan kurikuler pendidikan kewarganegaraan di atas, Sidi (2001) mengemukakan bahwa orientasi mata pelajaran pendidikan kewarganegaraan diarahkan untuk mencapai dua sasaran pokok yang seimbang (a) meningkatkan pengetahuan dan keterampilan siswa tentang etika, moral, dan asas-asas dalam hidup berbangsa dan bernegara; (b) membentuk sikap, perilaku, dan kepribadian sesuai dengan nilai-nilai luhur pancasila. Kedua sasaran ini hendaknya dapat dicapai secara serentak agar siswa tidak hanya mampu memahami pengetahuan tentang etika dan moral belaka, tetapi yang terpenting adalah agar siswa dapat dan mampu melakukan dalam pergaulan sehari-hari. Dengan kata lain, pendidikan kewarganegaraan bertujuan memberikan pengertian tentang hak dan kewajiban sebagai warga negara yang mampu memposisikan dirinya di era globalisasi ini.

Mata pelajaran pendidikan kewarganegaraan mempunyai peranan penting dalam pembentukan pemahaman, kepribadian, dan perubahan perilaku yang berkaitan dengan etika dan moral bangsa. Perubahan perilaku itu terlihat dari hasil belajar. Hasil belajar tampak sebagai terjadinya perubahan tingkah laku pada diri siswa yang dapat diamati dan diukur dalam bentuk perubahan pengetahuan, sikap, dan keterampilan (Hamalik, 2003).

Fudyartanto (2002) berpendapat bahwa hasil belajar adalah penguasaan sejumlah pengetahuan dan sejumlah keterampilan baru dan sesuatu sikap baru ataupun memperkuat sesuatu yang telah dikuasai sebelumnya, termasuk pemahaman dan penguasaan nilainilai. Pendapat senada juga dikemukakan oleh Daradjat (2002) yang mengemukakan bahwa hasil belajar selalu dinyatakan dalam bentuk perubahan tingkah laku yang meliputi tiga aspek: (1) aspek kognitif, meliputi perubahanperubahan kemampuan segi penguasaan pengetahuan dan perkembangan kemampuan yang diperlukan untuk menggunakan pengetahuan tersebut; (2) aspek afektif, meliputi perubahan-perubahan dalam segi sikap mental, perasaan dan kesadaran; (3) aspek psikomotor, meliputi perubahan-perubahan dalam segi bentuk tindakan motorik.

Dalam paparan tentang pengertian hasil belajar yang telah dikemukakan, dapat dimaknai bahwa perubahan-perubahan tingkah laku manusia dianggap sebagai hasil belajar yang mencakup aspek pengetahuan, keterampilan, sikap, dan nilai. Penilaian perubahan tingkah laku sebagai hasil belajar dapat dilakukan berdasarkan prinsip-prinsip : (a) kebutuhan-kebutuhan yang ada pada diri organisme yang memungkinkan tingkah laku yang bermotivasi, (b) motivasi yang mendasari perubahan tingkah laku itu, (c) tujuan yang mempengaruhi tingkah laku, (d) lingkungan yang menyediakan kesempatan untuk melakukan tingkah laku tertentu, (e) prosesproses yang mempengaruhi tingkah laku itu, (f) kapasitas dan abilitas yang mempengaruhi tingkah laku itu (Hamalik, 2003). 
Gagne (1995) mengemukakan hasil belajar terlihat dari berbagai macam kemampuan yaitu kemampuan dalam hal informasi verbal, kemahiran intelektual, pengaturan kegiatan kognitif, keterampilan motorik, dan sikap. Kemampuan-kemampuan itu dihasilkan karena usaha belajar dan harus dibuktikan dari hasil belajar. Dalam hal ini untuk memberikan hasil belajar yang lebih baik siswa selalu dituntut untuk memberikan hasil belajar secara nyata. Sejalan dengan hal tersebut Winkel (1996) mengemukakan bahwa hasil belajar akan nampak dalam prestasi belajar atau dalam produk yang dihasilkan oleh siswa.

Menurut Romiszowski,A.J. (1981) hasil belajar merupakan keluaran (output) dari suatu sistem pemrosesan masukan (input) dimana masukan dari sistem tersebut berupa bermacammacam informasi sedangkan keluarannya adalah perbuatan atau kinerja (performance). Romizowski juga berpendapat perbuatan merupakan petunjuk bahwa proses belajar telah terjadi dan hasil belajar dapat dikelompokkan ke dalam dua macam, yaitu pengetahuan dan keterampilan. Pengetahuan terdiri dari empat kategori yaitu: pengetahuan tentang fakta, Pengetahuan tentang konsep, pengetahuan tentang prinsip dan pengetahuan tentang prosedur. Keterampilan kognitif, keterampilan untuk bertindak atasi keterampilan motorik, keterampilan bereaksi atau bersikap dan keterampilan untuk bersosialisasi atau keterampilan berinteraksi.

Untuk mengetahui baik atau tidaknya hasil belajar, dapat dilakukan melalui tes hasil belajar. Syah (2003) menjelaskan tes hasil belajar adalah alat ukur yang digunakan untuk menentukan taraf keberhasilan sebuah proses pembelajaran atau untuk menentukan taraf keberhasilan sebuah program. Furqon seperti yang dikutif Rezeki (2004) menjelaskan bahwa tes adalah seperangkat rangsangan yang diberikan kepada seseorang dengan maksud untuk mendapatkan jawaban yang dapat dijadikan dasar bagi penetepan skor atau angka. Skor yang didasarkan pada sampel yang refresentatif dari tingkah laku peserta tes memiliki karakteristik yang sedang diukur, dan untuk memperoleh ukuran dan data hasil belajar adalah dengan mengetahui indikator yang dikaitkan dengan jenis prestasi yang hendak diukur.

Berdasarkan teori-teori di atas, yang berkenaan dengan pengertian hasil belajar, dapat disimpulkan bahwa hasil belajar pendidikan kewarganegaraan mengandung pengernbangan individu menjadi insan Tuhan, anggota keluarga, warga masyarakat, anggota organisasi, warga negara, dan sekaligus warga masyarakat global yang mampu hidup harmonis ditengah kehidupan bersama, tanpa kehilangan jati dirinya. Dengan demikian salah satu indikator dari hasil belajar pendidikan kewarganegaraan merupakan gambaran tingkat kesanggupan kognitif, dimana menurut Romiszowski (1981) diperoleh dalam bentuk pengetahuan dan keterampilan dalam bentuk pengetahuan meliputi fakta, konsep, prinsip dan prosedur. Fakta, konsep, prinsip dan prosedur akan berarti atau bermakna bagi siswa apabila dihubungkan dengan fakta yang ada di dalam kehidupan sehari-hari. Sedangkan bentuk keterampilan yang menggambarkan tingkat kesanggupan kognitif, yaitu keterampilan siswa menggunakan pikiran, guna menghadapi sesuatu peristiwa seperti pengambilan keputusan dan pemecahan masalah.

Untuk mengembangkan keterampilan dan strategi kognitif yang dimiliki siswa, Bloom (1982) mengembangkan sebuah taksonomi ranah kognitif dalam dua kelompok utama yaitu: (1) hapalan sederhana mengenai informasi dan (2) kegiatan intelektual. Jenjang yang paling rendah sebagai pengetahuan, sementara kemampuan berpikir yang lebih tinggi diklasifikasikan ke dalam lima jenjang, berpikir yang semakin lama semakin sulit yaitu, pemahaman, penerapan, analisis, evaluasi dan kreativitas. Taksonomi lain yang dikembangkan oleh Gagne dalam Jerrold E. Kemp (1994) terdiri atas sebuah urutan kognitif yaitu fakta, konsep, asas dan pemecahan masalah. Demikian juga hasil belajar pendidikan kewarganegaraan merupakan perubahan tingkah laku yang terjadi pada siswa yang dapat diamati dan diukur dalam bentuk perubahan pengetahuan, sikap, dan keterampilan. Dimana tingkah laku sebagai hasil belajar pendidikan kewarganegaraan dalam pengertian luas mencakup aspek-aspek kognitif, afektif dan psikomotorik. Perubahan aspek kognitif mencakup pengetahuan yang harus diketahui, dimengerti, dan diaplikasikan dalam pelaksanaan tugas tertentu seperti memecahkan masalah, membuat telaah atas suatu kasus. Perubahan aspek afektif berkaitan dengan perasaan, emosi, yang berhubungan terhadap sesuatu seperti setuju, tidak setuju, sering dan benci. Sedangkan perubahan psikomotorik berkaitan dengan 
Model pembelajaran adalah kerangka konseptual yang melukiskan prosedur sistematis dalam mengorganisasikan pengalaman belajar untuk mancapai tujuan belajar tertentu dan bersifat sabagai pedoman bagi perangsangan pembelajaran para guru dalam merencanakan dan melaksanakan aktifitas belajar mengajar. Arens (1997), mengemukakan bahwa suatu model pembelajaran dapat menggunakan sejumlah keterampilan metodologis dan prosedural, seperti merumuskan masalah, mengemukakan pertanyaan, berdiskusi dan memperdebatkan temuan, sehingga hasil akhir dari suatu pengembangan perangkat pembelajaran merupakan suatu sistem pembelajaran yang berupa perangkat materi dan strategi belajar mengajar yang secara empiris dan konsisten dapat mencapai tujuan pembelajaran tertentu.

Dari pengertian model pembelajaran yang telah dikemukakan di atas, dapat diketahui bahwa setiap model pembelajaran memberikan pola pembelajaran dalam membantu siswa untuk mencapai berbagai tujuan pembelajaran. Agar pola pembelajaran sesuai dengan desain pembelajaran, ada dua faktor yang terkait dalam setiap pemilihan model pembelajaran ; Pertama, model pembelajaran itu harus memenuhi tujuan bagi kepentingan guru untuk menjalankan proses pembelajaran ; kedua, model yang dipilih itu harus disesuaikan dengan keadaan struktur, suasana, dan lingkungan yang bisa dihadapi siswa (Miller, 2002).

Pembelajaran merupakan suatu proses yang sedemikian rupa untuk mencapai hasil yang diinginkan. Penentuan media, dan model yang tepat sangat membantu kelancaran proses pembelajaran. Pemilihan model pembelajaran berbasis portofolio merupakan langkah yang tepat sebab dapat menghidupkan suasana pembelajaran pendidikan kewarganegaraan. Proses yang berpusat pada siswa dimana ideide, gagasan, pendapat, sikap dan perbuatan siswa lahir dari hasil pengalaman siswa itu sendiri, yaitu pengalaman siswa yang menyangkut kepentingan bersama merupakan salah satu latar belakang pembelajaran berbasis portofolio (Denny, 2003).

Model pembelajaran portofolio merupakan model pembelajaran yang diadaptasi dari model "We are the People Project Citizen" yang dikembangkan oleh Center Civic Education (CCE) yang berkedudukan di Callabas, Amerika Serikat. Sampai saat ini telah diadaptasi oleh sekitar 50 negara termasuk Indonesia. Model ini bersifat generic- pedagogik, dan materinya dapat disesuaikan dengan kondisi masing-masing negara.

Portofolio berasal dari bahasa Inggris "portfolio" yang artinya dokumen atau suratsurat. Dapat juga diartikan sebagai kumpulan kertas-kertas berharga dari suatu pekerjaan tertentu. Pengertian portofolio disini adalah suatu kumpulan pekerjaan siswa dengan maksud tertentu dan terpadu yang diseleksi menurut panduan maksud tertentu dan terpadu serta diseleksi menurut panduan-panduan yang telah ditentukan. (Fajar, 2004:47). Panduanpanduan ini beragam tergantung pada mata pelajaran dan tujuan penilaian portofolio.

Budimansyah (2001:1) menjelaskan portofolio diartikan sebagai suatu wujud benda fisik, sebagai suatu proses sosial pedagogis maupun adjective. Sebagai suatu wujud benda fisik portofolio adalah bundel, yakni kumpulan atau dokumentasi hasil pekerjaan siswa yang disimpan pada satu bundel. Misalnya hasil tes awal (pre test), tugas-tugas, keterangan melaksanakan tugas terstruktur, hasil tes akhir (post test) dan sebagainya. Sebagai suatu proses pedagogis, portofolio adalah collection of learning experience yang terdapat dalam pikiran siswa baik yang berwujud pengetahuan (kognitif), keterampilan (skill), maupun nilai dan sikap (afektif). Adapun metode pembelajaran berbasis portofolio sebagai adjective, portofolio seringkali disandingkan dengan pembelajaran maka dikenal dengan pembelajaran berbasis portofolio (portofolio based learning, sedangkan jika disandingkan dengan konsep penilaian dikenal dengan istilah penilaian berbasis portofolio (portofolio based assesment).

Model pembelajaran konvensional adalah pendekatan pembelajaran yang masih dipakai dan digunakan pada saat ini. Pembelajaran pendidikan kewarganeraaan model ini, bentuk pembelajarannya menempatkan guru sebagai sumber tunggal (Suparman, 1997). Pendidikan pembelajaran tersebut menjadi pendekatan yang berpusat pada guru, guru menyampaikan materi pelajaran sesuai dengan rancangannya dan orientasi pembelajaran seluruhnya tertuju pada siswa. Sementara itu Sudjana (2002) mengatakan konvensional bercirikan antara lain; pembelajaran berorientasi pada materi dan berpusat pada guru, komunikasi yang terjadi cenderung satu arah, kegiatan lebih menekankan siswa mendengar dan mencatat seperlunya, suasana bertanya tidak muncul dari siswa, menyamaratakan kemampuan siswa, dan 
berorientasi pada target pencapaian kurikulum. Pendapat yang lain dikemukakan oleh Nawawi (2004) bahwa pembelajaran konvensional merupakan pendekatan pembelajaran yang menggunakan guru sebagai sumber tunggal dalam belajar, dengan demikian guru memegang kendali utama dalam menetapkan metode pembelajaran, dan menilai hasil belajar.

Berhasil atau tidak berhasil suatu pencapain tujuan dalam proses belajar mengajar dipengaruhi oleh banyak faktor yang antara lain adalah keadaan awal dan kemampuan awal belajar, baik secara individu maupun secara kelompok. Pada setiap kelas yang berisi sejumlah pelajar memiliki perbedaan dan motivasi, kemampuan, taraf pengetahuan, latar belakang sosial ekonomi dan sebagainya. Bloom (1982) mengemukakan dalam, proses belajar di sekolah, prestasi belajar yang diperoleh oleh pelajar sebelumya memiliki pengaruh yang kuat terhadap prestasi belajar berikutnya, lebih lanjut ia mengatakan hasil dari suatu kegiatan belajar mencerminkan ciri-ciri awal pebelajar yang akan digunakan untuk kegiatan berikutnya.

Reigeluth (2001) megidentifikasikan

7 jenis kemampuan awal yang dapat dipakai untuk memudahkan perolehan, pengorganisasian, dan pengungkapan kembali pengetahuan baru. Ketujuh jenis kemampuan ini adalah adalah : (1) pengetahuan bermakna tak terorganisasi (arbitrarily meaningful knowledge) sebagai tempat mengkaitkan pengetahuan hapalan (yang tak bermakna) untuk memudahkan retensi; (2) pengetahuan analogis (analogic knowledge) yang berada diluar isi yang sedang dibicarakan ; (3) pengetahuan tingkat yang lebih tinggi (superordinate knowledge) yang dapat berfungsi sebagai kerangka acuan bagi pengetahuan baru; (4) pengetahuan singkat (coordinate knowledge) yang dapat memenuhi fungsinya sebagai pengetahuan asosiatif dan komparatif; (5) pengetahuan tingkat yang lebih rendah (subordinate knowledge) yang berfungsi untuk mengkonkritkan pengetahuan baru atau juga penyediaan contoh-contoh; (6) pengetahuan pengalaman (experiental knowledge) yang memiliki fungsi sama dengan pengetahuan tingkat yang lebih rendah, yaitu untuk mengkonkritkan dan menyediakan contoh-contoh bagi pengetahuan baru, dan (7) strategi kognitif (cognitive strategy) yang menyediakan cara-cara mengolah pengetahuan baru, mulai dari penyediaan, penyimpanan, sampai pada pengungkapan kembali pengetahuan yang telah tersimpan dalam ingatan.

Mengidentifikasi kemampuan awal siswa juga bernilai sangat penting pada awal perencanaan pembelajaran bagi populasi sasaran tertentu. Menurut Gagne dan Briggs (1979) ada dua alasan mengapa keterampilanketerampilan intelektual memainkan peranan penting dalam merancang struktur bahan ajar. Pertama, hal ini merupakan jenis kemampuan yang mencerminkan apa yang dapat dilakukan siswa, dan berhubungan erat dengan deskripsi masalah hasil belajar siswa. Alasan kedua adalah keterampilan intelektual itu memiliki suatu harfiah kumulatif dengan kata lain mereka membangun satu sama lain dalam satu kebiasaan yang dapat diprediksi.

Dimiyati dan Mudjiono (2006) menekankan enam kegiatan dalam pembelajaran yaitu : (1) guru melaksanakan tugas pembelajaran, (2) siswa memilki motivasi, (3) siswa bersangkutan memiliki kemampuan awal belajar, (4) evaluasi belajar, (5) dampak pengajaran, dan (6) dampak pengiring.

Arah perkembangan dan kemampuan manusia dipengaruhi oleh kekuatan secara serempak yaitu bakat dan sifat-sifat yang dibawa sejak lahir dan pengalaman yang diperoleh dari lingkungannya. Oleh karena itu kemampuan dasar manusia perlu dikembangkan sehingga, proses pembelajaran berjalan dan dengan baik dan untuk melanjutkan pelajaran berikutnya (Surachmad dan Silitonga, 1991:31). Kemampuan awal merupakan faktor penting sebagai bekal siswa sebelum memasuki kegiatan pembelajaran. Kemampaun awal adalah kesanggupan, kecakapan dan kekuatan (Sastropraja, 1979). Kemampuan awal adalah kemampuan yang dimiliki siswa pada saat memasuki pembelajaran, kemampuan ini merupakan dasar bagi kegiatan belajar yang akan diikuti oleh siswa selanjutnya (Dick \& Carey, 2005). Jadi dalam proses belajar mengajar disekolah, hasil belajar dipengaruhi oleh kemampuan awal siswa, hasil tersebut mencerminkan ciri-ciri awal siswa yang akan digunakan untuk melanjutkan kegiatan berikutnya. Berdasarkan penjelasan ini maka dapat dikemukakan yang dimaksud dengan kemampuan awal adalah kemampuan siswa terhadap sesuatu yang diperoleh dari kegiatan siswa sebelumnya, untuk digunakan pada kegiatan pembelajaran yang akan datang.

Pentingnya kemampuan awal disebabkan karena mempunyai implikasi 
terhadap penyusunan bahan ajar dan sistem pembelajaran. Jadi kemampuan awal ini merupakan informasi yang dibutuhkan untuk penyusunan program pembelajaran agar tercapai tujuan yang telah ditentukan (Suparman 1997). Dengan diketahui kemampuan awal siswa sebelumnya, maka akan mudah menetapkan metode atan pendekatan yang akan digunakan dalam kegiatan pembelajaran.

Rumusan masalah penelitian ini adalah: (1) Apakah siswa Madrasah Aliyah Laboratorium Kelas $\mathrm{X}$ yang diajar dengan model pembelajaran berbasis portofolio akan memperoleh hasil belajar pendidikan kewarganegaraan lebih tinggi dibandingkan dengan siswa yang diajar dengan model pembelajaran konvensional ?; (2) Apakah siswa Madrasah Aliyah Laboratorium Kelas X yang memiliki kemampuan awal tinggi menunjukkan hasil belajar yang lebih tinggi, dibandingkan dengan siswa berkemampuan awal rendah?; dan (3) Apakah ada interaksi antara model pembelajaran berbasis portofolio dan kemampuan awal dalam mempengaruhi hasil belajar pendidikan kewarganegaraan siswa Madrasah Aliyah Laboratorium kelas X ?

\section{METODE}

Penelitian ini dilakukan di Madrasah Aliyah Laboratorium IAIN SU Medan. Populasi dalam penelitian ini adalah seluruh siswa Kelas X Madrasah Aliyah Laboratorium IAIN SU medan, terdiri dari 4 kelas dengan jumlah siswa yaitu; 122 orang. Teknik pengambilan sampel dalam penelitian ini yaitu dilakukan secara cluster random sampling melalui undian yakni, dari 4 kelas yang ada diperoleh 2 kelas eksperimen. Dari 2 kelas yang telah terpilih sebagai sampel penelitian, selanjutnya melalui pengundian maka kelas $\mathrm{X}^{1}$ yang berjumlah 30 orang terpilih sebagai kelas yang akan diajar dengan model pembelajaran konvensional, sedang kelas $\mathrm{X}^{2}$ yang berjumlah 30 orang terpilih sebagai kelas yang akan diajar dengan menggunakan model pembelajaran portofolio.

Penelitian ini dilakukan dalam bentuk quasi Ekspriement. Penelitian ini melibatkan dua kelompok sampel masing-masing ditetapkan sebagai kelompok eksperimen dan kelompok kontrol. Kelompok eksperimen diberlakukan model pembelajaran berbasis portofolio dan kelompok kontrol diberlakukan model pembelajaran konvensional pada pelajaran pendidikan kewarganegaraan. Akhir dari eksperimen ini diharapkan mendapat informasi tentang perbedaan hasil belajar pendidikan kewarganegaraan siswa melalui pembelajaran berbasis portofolio yang dibandingkan dengan konvensional dengan mengelompokkan sampel penelitian menjadi dua kelompok yaitu siswa yang memiliki kemampuan awal tinggi dan siswa yang memiliki kemampuan awal rendah.

Desain penelitian ini digunakan disain faktorial 2 x 2, melalui desain ini akan dibandingkan pengaruh antara model pembelajaran berbasis portofolio dan konvensional terhadap hasil belajar pendidikan kewarganegaraan ditinjau dari kemampuan awal. Desain Penelitian seperti pada Tabel 1 berikut:

Tabel 1. Disain Penelitian Faktorial 2 x 2

\begin{tabular}{|c|c|c|}
\hline $\begin{array}{l}\text { Model Pembelajaran (A) } \\
\text { Kemampuan Awal (K) }\end{array}$ & Portofolio $\mathrm{A}_{1}$ & Konvensional $\mathrm{A}_{2}$ \\
\hline Tinggi & $\begin{array}{ll}A_{1} & K_{1} \\
\end{array}$ & $\begin{array}{ll}\mathrm{A}_{2} & \mathrm{~K}_{1}\end{array}$ \\
\hline Rendah $\left(\mathrm{K}_{2}\right)$ & $\mathrm{A}_{1}$ IKennggun & kan uji LilAiefork dan uj \\
\hline
\end{tabular}

untuk pengujian hipotesis adalah Analisis Varians (ANAVA) dua jalan (Two-way Anova) dengan taraf signifikan $\alpha=0,05$, yang kemudian dilanjutkan dengan uji Tuckey jika analisis varians menunjukkan adanya interaksi.

Sebelum teknik analisis ini digunakan maka terlebih dahulu dilakukan uji persyaratan analisis, dilakukan dengan uji normalitas
Setelah melakukan pengujian persyarat analisis, selanjutnya dilakukan pengujian ANAVA dua jalur.

Untuk keperluan pengujian hipotesis, maka perlu dirumuskan hipotesis statistik sebagai berikut:

1. Ho : $\mu A_{1}=\mu A_{2}$

$\mathrm{Ha}: \mu \mathrm{A}_{1}>\mu \mathrm{A}_{2}$

2. Ho $: \mu \mathrm{K}_{1}=\mu \mathrm{K}_{2}$ 
$\mathrm{Ha}: \mu \mathrm{K}_{1}>\mu \mathrm{K}_{2}$

3. Ho : interaksi $\mathrm{A}><\mathrm{K}=0$

$\mathrm{Ha}$ : interaksi $\mathrm{A}><\mathrm{K} \neq 0$

HASIL DAN PEMBAHASAN

Hasil

Tabel 2. Rangkuman Data Hasil Penelitian
Pengujian Hipotesis dilakukan dengan menggunakan analisis varians. Untuk keperluan analisis varians, data yang diperlukan dapat dilihat pada Tabel 4.16, sedangkan data lengkap secara keseluruhan dapat dilihat pada lampiran.

\begin{tabular}{|c|c|c|c|c|}
\hline \multicolumn{2}{|c|}{ Variabel } & \multicolumn{2}{|c|}{ Model Pembelajaran } & \multirow{2}{*}{ Total } \\
\hline \multirow{9}{*}{ 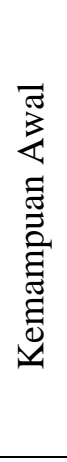 } & \multirow{5}{*}{ Tinggi } & Portofolio & Konvensional & \\
\hline & & $\mathrm{n}_{1}=15$ & $\mathrm{n}_{3}=15$ & $\mathrm{n}=30$ \\
\hline & & $\bar{X}=24,267$ & $\bar{X}=20,200$ & $\bar{X}=22,233$ \\
\hline & & $\sum \mathrm{x}_{1}=364$ & $\sum \mathrm{x}_{3}=303$ & $\sum x=667$ \\
\hline & & $\mathrm{s} \quad=2,520$ & $\mathrm{~s} \quad=3,075$ & $\mathrm{~s}=2,798$ \\
\hline & \multirow{4}{*}{ Rendah } & $\mathrm{n}_{2}=15$ & $\mathrm{n}_{4}=15$ & $\mathrm{n}=30$ \\
\hline & & $\bar{X}=19,467$ & $\bar{X}=19,200$ & $\bar{X}=19,333$ \\
\hline & & $\sum x_{2}=292$ & $\sum \mathrm{x}_{4}=288$ & $\sum x=580$ \\
\hline & & $\mathrm{s} \quad=2,973$ & $s \quad=2,077$ & $\mathrm{~s} \quad=2,525$ \\
\hline \multirow{4}{*}{\multicolumn{2}{|c|}{ Total }} & $\mathrm{n}=30$ & $\mathrm{n}=30$ & $\mathrm{n}=60$ \\
\hline & & $\bar{X}=21,867$ & $\bar{X}=19,700$ & $\bar{X}=20,783$ \\
\hline & & $\sum x=656$ & $\sum x=591$ & $\sum x=1247$ \\
\hline & & $\mathrm{s}=2,747$ & $\mathrm{~s}=2,576$ & $\mathrm{~s}=2,661$ \\
\hline
\end{tabular}

Setelah data penelitian dianalisis maka diperoleh hasil perhitungan ANAVA seperti yang disajikan pada Tabel 3 .

Tabel 3. Hasil Perhitungan ANAVA

\begin{tabular}{|c|c|c|c|c|c|}
\hline Sumber Varians & $\mathbf{d k}$ & JK & RJK & $\mathbf{F}_{\text {Hitung }}$ & $\frac{F_{\text {Tabel }}}{\alpha \mathbf{0 , 0 5}}$ \\
\hline Antar Kolom (A) & 1 & 70,417 & 70,417 & 9,275 & \multirow{2}{*}{4,013} \\
\hline Antar Baris $(\mathrm{K})$ & 1 & 126,150 & 126.150 & 7,310 & \\
\hline Interaksi $(\mathrm{A} \times \mathrm{K})$ & 1 & 54,150 & 54,150 & 7,479 & \multirow{3}{*}{2,761} \\
\hline Antar Kelompok A dan K & 3 & 250,717 & 83,572 & \multirow{2}{*}{11,542} & \\
\hline Dalam Kelompok (Antar Sel) & 56 & 405,467 & 7,240 & & \\
\hline Total Reduksi & 59 & 656,183 & - & - & - \\
\hline
\end{tabular}

Pengujian lanjutan dengan uji Tuckey didasarkan pada sel setiap sampel ANAVA yang memiliki ukuran sampel yang sama dan nilai kritik $\alpha$ tidak kontras artinya semua taraf signifikan $(\alpha)$ bisa digunakan. Namun dalam hal ini kritik $\alpha$ yang diambil taraf signifikan 5\% untuk derajat nilai kebebasan sesuai dengan jumlah kelompok eksperimen. Berdasarkan perhitungan ANAVA, diperoleh $\mathrm{RJK}_{\text {dalam kelompok }}$ sebagai RJK galat atau disebut juga dengan varians dalam sel $\mathrm{s}_{\mathrm{w}}{ }_{\mathrm{w}}=0,491$, maka dihitung perumusan uji Tuckey. Perhitungan lengkap dapat dilihat pada lampiran, selanjutnya pada Tabel 4.18 ditunjukkan uji perbandingan ganda dengan menggunakan uji Tuckey.

Tabel 4.18. Ringkasan Hasil Uji Perbandingan ganda dengan uji Tuckey

\begin{tabular}{|l|c|c|c|c|}
\hline \multirow{2}{*}{$\begin{array}{c}\text { Kelompok Skor Rata-rata yang } \\
\text { dibandingkan }\end{array}$} & \multirow{2}{*}{ Q-hitung } & \multicolumn{2}{|c|}{ Q-tabel } & \multirow{2}{*}{ Kesimpulan } \\
\cline { 3 - 4 } & & $\alpha=0,05$ & $\alpha=0,01$ & \\
\hline MPBP dengan MPK & 4,410 & 2,89 & 3,89 & $\mathrm{H}_{\mathrm{o}}$ ditolak \\
\hline KAT dengan KAR & 5,903 & 2,89 & 3,89 & $\mathrm{H}_{\mathrm{o}}$ ditolak \\
\hline MPBP-KAT dengan MPK-KAT & 5,602 & 3.03 & 4,21 & $\mathrm{H}_{\mathrm{o}}$ ditolak \\
\hline
\end{tabular}




\begin{tabular}{|l|c|c|c|c|}
\hline MPBP-KAR dengan MPK-KAR & 0,403 & 3.03 & 4,21 & $\mathrm{H}_{\mathrm{o}}$ diterima \\
\hline MPBP-KAT dengan MPBP-KAR & 6,745 & 3.03 & 4,21 & $\mathrm{H}_{\mathrm{o}}$ ditolak \\
\hline MPK- KAT dengan MPK- KAR & 1,476 & 3.03 & 4,21 & $\mathrm{H}_{\mathrm{o}}$ diterima \\
\hline MPBP-KAT dengan MPK- KAR & 8,497 & 3.03 & 4,21 & $\mathrm{H}_{\mathrm{o}}$ ditolak \\
\hline MPBP-KAR dengan MPK- KAT & 0,939 & 3.03 & 4,21 & $\mathrm{H}_{\mathrm{o}}$ diterima \\
\hline
\end{tabular}

Berdasarkan data hasil belajar pendidikan kewarganegaraan siswa, bahwa rata-rata hitung yang diperoleh siswa dan hasil pengujian hipotesis, dapat digambarkan asumsi interaksi yang terjadi antara model pembelajaran dengan kemampuan awal dalam mempengaruhi hasil belajar pendidikan kewarganegaraan siswa seperti pada gambar 1.

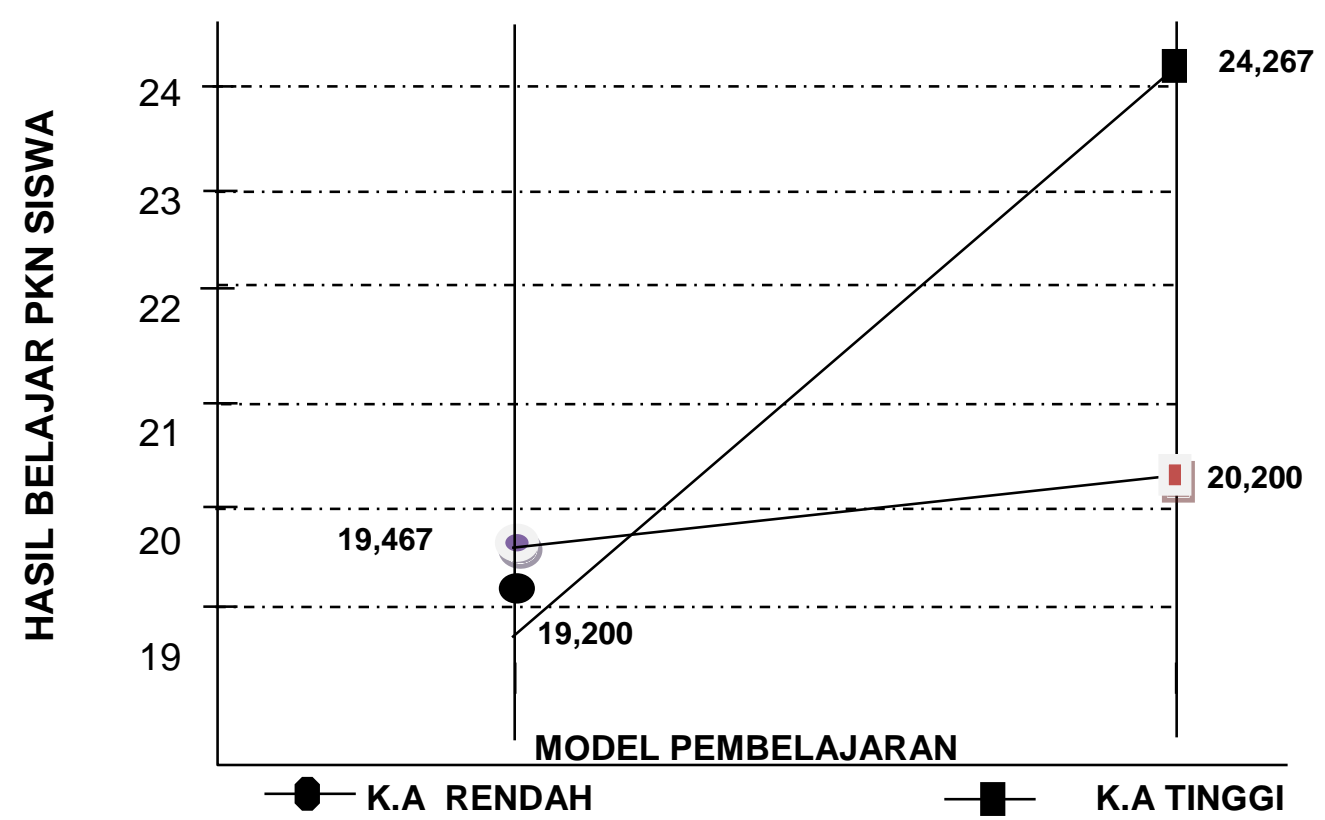

Gambar 1. Interaksi antara model pembelajaran dan kemampuan awal dalam mempengaruhi hasil belajar pendidikan kewarganegaraan siswa.

\section{Pembahasan}

Berdasarkan temuan yang dikemukakan secara umum perbedaan antara model pembelajaran berbasis portofolio dengan model pembelajaran konvensional terletak dalam berbagai aspek antara lain, bahwa model pembelajaran konvensional menunjukkan ciri suatu proses pembelajaran yang mengharapkan guru menyediakan buku ajar (materi) sebagai sumber informasi dan terpusat pada siswa, sedangkan pada model pembelajaran portofolio di dalam proses pembelajaran siswa akan menemukan sendiri lebih banyak informasi melalui pendekatan dan strategi yang dipersiapkan oleh guru. Pembelajaran dengan menggunakan model pembelajaran konvensional dan model pembelajaran portofolio dipandang dapat mengembangkan model pembelajaran yang mampu membina siswa kearah cara belajar perilaku, hanya saja dengan menggunakan model pembelajaran konvensional lebih terpusat penekanannya terhadap materi bahan ajar yang dipelajari, sedangkan dengan model pembelajaran berbasis portofolio akan memberikan keluwesan bagi siswa untuk mengkaji materi yang lain yang terkait dengan usaha siswa untuk meningkatkan pengetahuan serta kemampuan mereka dalam menangani permasalahan yang terjadi pada kehidupan sehari-hari.

Seperti diketahui bahwa penguasaan atas kemampuan awal siswa sangat berpengaruh terhadap kemampuan siswa dalam mengembangkan materi yang dipelajari. Penguasaan konsep kemampuan awal membantu siswa dalam melakukan analisis kesalahan yang mungkin terjadi pada penemuan pengetahuan yang baru. Dengan demikian bagi siswa yang memiliki kemampuan awal di dalam struktur kognitifnya untuk memahami konsep akan lebih baik, dan siswa akan lebih mudah mempelajari suatu konsep atau prinsip terlebih 
dahulu. Dengan adanya pengetahuan dasar seperti itu, siswa akan dapat menyusun kesimpulan dengan lebih mudah tentang apa yang dipelajari. Setelah itu siswa dapat mengaplikasikan konsep-konsep atau prinsipprinsip itu dalam pemecahan masalah yang dihadapi baik dalam kegiatan di lapangan, maupun dalam kehidupan masyarakat secara langsung. Kondisi ini teruji secara empiris dengan temuan penelitian yang membuktikan bahwa terdapat perbedaan hasil belajar pendidikan kewarganegaraan siswa yang signifikan antara kelompok yang memiliki kemampuan awal tinggi dengan siswa yang memiliki kemampuan awal rendah. Hasil temuan membuktikan bahwa rata-rata hitung skor hasil belajar pendidikan kewarganegaraan siswa yang memiliki kemampuan awal tinggi $(22,233)$ lebih tinggi dari rata-rata hitung skor hasil belajar pendidikan kewarganegaraan siswa yang memiliki kemampuan awal rendah $(19,333)$. Hal ini dapat dipahami bahwa siswa yang memiliki kemampuan awal tinggi, akan lebih mudah mentransfer pengetahuannya dan akan termotivasi untuk memecahkan masalah yang dihadapi, sebaliknya bagi siswa yang memiliki kemampuan awal rendah kurang bergairah dalam belajar, kurang berani dalam mengajukan pertanyaan atau memberi komentar terhadap materi yang sedang dipelajari, serta cenderung kurang aktif dalam proses pembelajaran.

Kemampuan awal siswa sangat berpengaruh terhadap peningkatan hasil belajar pendidikan kewarganegaraan siswa. Hal ini terbukti dari hasil temuan yang menguatkan bahwa siswa yang kemampuan awal tinggi lebih unggul dan lebih baik, serta lebih menguasai suasana proses pembelajaran, dan lebih aktif dalam kelas serta lebih dominan dalam situasi tanya jawab. Sedangkan siswa yang berkemampuan awal rendah, cenderung lebih pasif, dan kelihatan ragu-ragu dalam memberikan gagasan, bahkan cenderung lambat atau ketinggalan dalam memahami isi materi yang sedang diajarkan. Sebaliknya pada pembelajaran konvensional bagi siswa yang memiliki kemampuan awal rendah hasil belajar pendidikan kewarganegaraan siswa sama, bila dibandingkan dengan hasil belajar siswa yang memiliki kemampuan awal tinggi. Hal ini terbukti dari hasil temuan yang menguatkan bahwa hasil belajar pendidikan kewarganegaraan siswa yang memiliki kemampuan awal rendah sama bila dibandingkan dengan hasil belajar siswa yang memiliki kemampuan awal tinggi.

Secara keseluruhan hasil belajar siswa yang memiliki kemampuan awal rendah pada perlakuan model pembelajaran berbasis portofolio dan model pembelajaran konvensional bila dibandingkan tidak terdapat perbedaan yang signifikan, ternyata hasilnya sama. Hal ini terbukti dari hasil temuan yang menguatkan bahwa hasil belajar pendidikan kewarganegaraan siswa yang memiliki kemampuan awal rendah pada perlakuan model pembelajaran berbasis portofolio tidak berbeda dengan hasil belajar yang memiliki kemampuan awal rendah pada pembelajaran konvensional. Berdasarkan hasil penelitian yang diperoleh memberikan gambaran bahwa dalam perlakuan model pembelajaran portofolio dan model pembelajaran konvensional sangat perlu untuk memperhitungkan dan memperhatikan kemampuan awal yang dimiliki oleh siswa.

Dari hasil perhitungan statistik deskriptif, terbukti bahwa terdapat interaksi antara model pembelajaran dengan kemampuan awal dalam mempengaruhi hasil belajar siswa pada model pembelajaran portofolio dan pada model pembelajaran konvensional. Hal ini memberikan indikasi bahwa perlakuan terhadap kelompok siswa yang memiliki kemampuan awal tinggi berbeda dengan kelompok siswa yang memiliki kemampuan awal rendah, artinya bahwa salah satu dari kedua kelompok akan menghasilkan hasil belajar pendidikan kewarganegaraan siswa yang lebih baik bila diajar dengan model pembelajaran berbasis portofolio, dan yang lainnya akan tidak terdapat perbadaan bila diajar dengan pembelajaran konvensional. Berdasarkan dari hasil temuan penelitian, mencerminkan bahwa bagi kelompok siswa yang memiliki kemampuan awal tinggi, mereka memperoleh rata-rata hitung skor hasil belajar pendidikan kewarganegaraan siswa lebih tinggi bila diajar dengan menggunakan model pembelajaran portofolio. Untuk kelompok siswa yang memiliki kemampuan awal rendah, mereka memperoleh rata-rata hitung skor hasil belajar lebih tinggi bila diajar dengan menggunakan model pembelajaran portofolio. Hal ini dapat dijelaskan bahwa untuk siswa yang memiliki kemampuan awal tinggi akan lebih menunjukkan aktifitas yang lebih aktif dalam pembelajaran, lebih senang dengan berdiskusi dan tertarik dengan penemuan baru serta memecahkan masalah, sehingga karakteristik ini akan lebih sesuai model pembelajaran 
berbasis portofolio. Sebaliknya siswa kemampuan awal rendah, mereka selalu raguragu dalam mengungkapkan pendapatnya, cenderung kurang aktif, hal ini disebabkan akibat kurangnya pengetahuan yang dimiliki, sehingga mereka lebih senang untuk mencari informasi melalui materi pembelajaran yang disediakan dengan membaca dan membuat rangkuman sendiri, sehingga kondisi ini akan membantu untuk meningkatkan hasil belajar pendidikan kewarganegaraan mereka.

Berdasarkan temuan ini memberikan gambaran bahwa penerapan model pembelajaran terhadap hasil belajar pendidikan kewarganegaraan perlu memperhatikan kemampuan awal yang dimiliki oleh siswa untuk membantu siswa mencapai hasil belajar yang lebih baik. Dan penemuan penelitian yang lebih unik menunjukkan bahwa hasil belajar siswa untuk kelompok yang memiliki kemampuan awal tinggi yang diajar dengan menggunakan model pembelajaran barbasis portofolio berbeda nyata dan sangat signifikan dengan kelompok siswa yang diajar dengan model pembelajaran konvensional. Hal ini memberikan indikasi bahwa model pembelajaran barbasis portofolio memang memberikan pengaruh yang lebih dominan dalam meningkatkan hasil belajar siswa, sedangkan untuk dua kelompok perlakuan yang lainnya tidak menunjukkan perbedaan rata-rata hitung skor dari hasil belajar pendidikan kewarganegaraan siswa yang signifikan. Artinya bahwa interaksi antara model pembelajaran dengan kemampuan awal terjadi rata-rata hitung skor hasil belajar siswa pada kemampuan rendah, sehingga tercermin bahwa rata-rata hitung skor hasil pendidikan kewarganegaraan siswa yang lebih tinggi didominasi pada kelompok model pembelajaran barbasis portofolio baik untuk siswa yang memiliki kemampuan awal tinggi maupun rendah.

Hasil penelitian ini juga memberikan gambaran bahwa hasil belajar siswa yang diajar dengan model pembelajaran barbasis portofolio, menunjukkan kecenderungan untuk memperoleh hasil belajar yang lebih baik bagi siswa yang memiliki kemampuan awal tinggi. Sedangkan bagi siswa yang diajar dengan model pembelajaran konvensional, menunjukkan perubahan peningkatan hasil belajar pendidikan kewarganegaraan siswa yang signifikan antara kelompok siswa yang memiliki kemampuan awal tinggi dengan kelompok siswa yang memiliki kemampuan awal rendah.

Dari hasil penelitian yang dilakukan, diperoleh hasil belajar siswa yang diajarkan dengan model pembelajaran portofolio lebih baik bila dibandingkan dengan hasil belajar siswa yang diajar dengan pembelajaran konvensional. Temuan ini mendukung hasil penelitian Rezeki (2004) yang menyatakan bahwa strategi pembelajaran konstruktivisme mendorong siswa bersikap dan bertindak ilmiah, dan memberikan pengalaman belajar siswa yang dapat mengaktifkan siswa untuk terlibat secara fisik, emosi, dan mental dalam kegiatan pembelajaran sehingga terdapat perbedaan hasil belajar siswa yang mengikuti strategi pembelajaran konstruktivisme dengan siswa yang mengikuti strategi pembelajaran konvensional. Lebih lanjut dinyatakan bahwa siswa yang diajar dengan strategi pembelajaran konstruktivisme memperoleh hasil belajar yang lebih baik dari pada siswa yang diajar dengan strategi pembelajaran konvensional. Hasil penelitian ini juga relevan dengan hasil penelitian yang diperoleh oleh Darajat (2004) yang menyimpulkan bahwa metode pembelajaran discoveri dengan bimbingan yang lebih efektif digunakan dari pada metode konvensional dalam meningkatkan hasil belajar siswa. Hasil penelitian ini mendukung penelitian Rasyid (2004) bahwa strategi pembelajaran kooperatif sangat efektif untuk menumbuhkan perhatian, kepercayaan diri, keaktifan, dan menyenangkan siswa sehingga hasil belajar siswa yang diajar dengan strategi kooperatif ini lebih tinggi dibandingkan dengan yang diajar dengan strategi pembelajaran konvensional. Berdasarkan uraian di atas, maka jelas bahwa penggunaan model pembelajaran barbasis portofolio dan model pembelajaran konvensional memberikan hasil belajar siswa yang berbeda, hal ini karena dipengaruhi oleh faktor-faktor: (1) dampak penyerta dari kegiatan model pembelajaran yang mampu meningkatkan kemampuan berkomunikasi, (2) perkembangan berfikir kreatif siswa lebih terlatih dan memecahkan atas berbagai permasalahan yang dihadapi, (3) keterlibatan keaktifan siswa dalam menentukan struktur pengetahuan yang baru.

Hasil pengujian hipotesis menunjukkan bahwa hasil belajar siswa yang memiliki kemampuan awal tinggi berbeda dengan siswa yang memiliki kemampuan awal rendah. Siswa yang memiliki kemampuan awal tinggi cenderung lebih tinggi hasil belajarnya 
dibanding dengan siswa yang memiliki kemampuan awal rendah. Hal ini dapat dipahami karena: (1) siswa yang memiliki kemampuan awal tinggi berkecenderungan berfikir secara sistematis, kritis, logis dan analitis. Berbeda dengan siswa yang memiliki kemampuan awal rendah yang aktivitas berpikirnya berdasarkan pada realitas yang ada dan yang mereka serap melalui indra fisik. Hal ini menyebabkan siswa yang memiliki kemampuan awal rendah kurang mampu mengembangkan kemampuan bernalarnya melalui proses penelaahan bila dibandingkan dengan siswa yang memiliki kemampuan awal tinggi, kemampuan menanggapi suatu permasalahan bagi siswa yang memiliki kemampuan awal tinggi tampaknya lebih baik dibandingkan dengan siswa yang memiliki kemampuan awal rendah. Seorang siswa yang memiliki kemampuan awal tinggi dalam mengelola informasi cenderung menggunakan peranan akal yang kuat disamping penguasaan atas prinsip, konsep, dan generalisasi. Siswa yang memiliki kemampuan awal tinggi tidak memerlukan banyak permasalahan didalam proses belajarnya bila dibandingkan dengan siswa yang memiliki

Berdasarkan hasil pengujian hipotesis ketiga, dan dengan memperhatikan temuan penelitian, serta hasil uji lanjutan dengan menggunakan uji Tuckey, terbukti adanya interaksi antara model pembelajaran dan kemampuan awal terhadap hasil belajar pendidikan kewarganegaraan siswa. Hasil dari penelitian ini menunjukkan bahwa model pembelajaran berbasis portofolio memberikan pengaruh terhadap hasil belajar yang lebih baik, bila digunakan kepada kelompok siswa yang memiliki kemampuan awal tinggi dibandingkan dengan kelompok siswa memiliki kemampuan awal rendah.

Model pembelajaran berbasis portofolio menekankan pada kegiatan siswa lebih aktif, hal ini hanya dapat diterapkan pada siswa yang memiliki kemampuan awal tinggi. Situasi belajar dapat dikondisikan jika terdapat ketergantungan positif antara siswa yang satu dengan siswa yang lainnya. Hasil penelitian ini mendukung pernyataan Setiawan (2003) yang mengemukakan bahwa model pembelajaran berbasis portofolio dapat menghidupkan suasana pembelajaran sebab proses yang berpusat pada siswa, dimana ide-ide, gagasangagasan, pendapat, sikap dan perbuatan siswa lahir dari hasil pengalaman siswa itu sendiri, yaitu pengalaman siswa yang menyangkut kepentingan bersama. Disisi yang lain bagi siswa yang memilik kemampuan awal tinggi diajar dengan model pembelajaran konvensional cenderung hasil belajarnya rendah, sebab model pembelajaran konvensional didominasi oleh guru, sehingga keinginan, kreatifitas, ide-ide siswa yang memilik kemampuan awal tinggi untuk mengetahui sebab-sebab dari suatu persoalan dengan kemampuan yang ada pada dirinya tidak terealisasikan dengan baik, yang dapat mengakibatkan rendahnya hasil belajarnya.

Sebaliknya siswa yang memiliki memiliki kemampuan awal rendah lebih baik hasil belajarnya jika diajar dengan model pembelajaran konvensional dibandingkan dengan model pembelajaran berbasis portofolio. Dalam hal ini siswa yang memiliki memiliki kemampuan awal rendah cenderung tidak membutuhkan siswa yang lainnya dalam memecahkan permasalahan belajar. Bagi siswa yang memiliki kemampuan awal rendah akan belajar menurut kapasitasnya masing-masing. Mereka saling berkompetisi untuk mendapatkan hasil belajar yang lebih baik. Dengan demikian siswa yang memiliki kemampuan awal rendah lebih tepat jika diajar dengan model pembelajaran konvensional sebab dalam model pembelajaran konvensional guru merupakan sumber dalam memecahkan masalah belajar, menggunakan penjelasan secara verbal, dan komunikasi cenderung bersifat satu arah. Penelitian ini mendukung pendapat Suparman (1997) bahwa pembelajaran konvensional menempatkan guru sebagai satu-satunya sumber belajar, dan juga pendapat Nawawi (2004) bahwa strategi pembelajaran konvensional merupakan pembelajaran yang strategi pembelajarannya menggunakan guru sebagai satu-satunya sumber belajar, demikian juga pendapat Ahmadi dan Supriono (1991) bahwa pembelajaran konvensional adalah pembelajaran yang menggunakan penjelasan secara verbal, dan komunikasi biasanya bersifat satu arah, dan pendapat Nasution (1987) bahwa pembelajaran konvensional memiliki ciri pembelajaran yang disajikan kepada kelompok atau sebagai keseluruhan tanpa memperhatikan siswa secara individual.

\section{PENUTUP \\ Simpulan}

Berdasarkan hasil penelitian dan pembahasan yang dikemukakan, maka dapat ditarik beberapa simpulan sebagaimana di bawah ini : 
1. Penerapan model pembelajaran berbasis portofolio memberikan pengaruh terhadap hasil belajar pendidikan kewarganegaraan siswa yang lebih tinggi bila dibandingkan dengan model pembelajaran konvensional. Hal ini dapat dilihat dari skor rata-rata hitung hasil belajar yang diperoleh siswa pada kelompok yang diajar dengan menggunakan model pembelajaran berbasis portofolio lebih tinggi dibanding kelompok siswa yang diajar dengan menggunakan model pembelajaran konvensional.

2. Kemampuan awal siswa mempengaruhi hasil belajar pendidikan kewarganegaraan siswa, bagi kelompok siswa yang memiliki kemampuan awal tinggi memperoleh hasil belajar yang lebih tinggi bila dibandingkan dengan kelompok siswa yang memiliki kemampuan awal rendah.

3. Terdapat interaksi antara model pembelajaran dengan kemampuan awal dalam mempengaruhi hasil belajar siswa pada model pembelajaran portofolio dan model pembelajaran konvensional. Hal ini terbukti dari hasil pengujian lanjutan mendapat simpulan bahwa kelompok siswa yang memiliki kemampuan awal tinggi hasil belajarnya lebih tinggi yang diajar dengan menggunakan model pembelajaran portofolio dibandingkan dengan siswa yang diajar model pembelajaran konvensional.

\section{Saran}

1. Kepada Sekolah agar menghimbau kepada guru-guru untuk menggunakan model pembelajaran portofolio dalam kegiatan pembelajaran, yang disesuaikan dengan materi-materi yang diajarkan, karena melalui penelitian ini terbukti model pembelajarn portofolio dapat meningkatkan hasil belajar siswa.

2. Kepada guru diharapkan agar dapat melatih keterampilan dalam menggunakan model pembelajaran portofolio, dan memahami kemampuan awal siswa, serta kondisi siswa dalam proses pembelajaran agar siswa mampu menemukan dan mengembangkan pengetahuannya sendiri.

3. Bagi guru yang mengajar mata pelajaran pendidikan kewarganegaraan agar dapat menerapkan model pembelajaran portofolio, guna meningkatkan kompetensi siswa dan hasil belajar pendidikan kewarganegaraan. Untuk menerapkan model pembelajaran tersebut diharapkan guru selalu berusaha menyusun perencanaan yang sesuai dengan karakteristik siswa, materi pelajaran, serta menambah wawasan tentang teori belajar dan model pembelajaran yang inovatif.

4. Diharapkan kepada guru yang akan menerapkan model pembelajaran portofolio agar mengidentifikasi kemampuan awal siswa. Hal ini dilakukan untuk dapat memilih perlakuan yang akan diberikan siswa.

5. Perlu diadakan pendidikan dan pelatihan bagi guru-guru tentang model pembelajaran portofolio, khususnya guru mata pelajaran pendidikan kewarganegaraan dan umumnya guru-guru mata pelajaran sosial karena temuan penelitian ini menemukan bahwa model pembelajaran berbasis portofolio terbukti memberikan hasil belajar yang lebih baik terhadap hasil belajar pendidikan kewarganegaraan siswa bila dibandingkan model pembelajaran konvensional.

\section{DAFTAR PUSTAKA}

Ariani, Ida. (2000). Pengaruh Pembelajaran Assesmen Portofolio Terhadap Pencapaian Ketuntasan Belajar. Tesis. Bandung. Universitas Pendidikan.

Arends. (1997). Classroom Instruction And Management.The Mc Graw- Hill Companies, Inc.

Ahmadi, A, dkk. (2000). Transpormasi Pendidikan Memasuki Millenium Ketiga. Yogyakarta: Kanasius.

Badiran, M .(2006). Pengembangan Model Pembelajaran Teori Seni Rupa. Jurnal Tabularasa Vol. 03 Medan: PPs Unimed.

Bloom, B.S et all. (1982). Taxonomy of Education Objektives: The Clasification Of Education Goods. Handbook I : Cognitive Domain. New York : Logman Inc.

Boediono, dkk. (2001). Kurikulum Berbasis Kompetensi. Jakarta: Balitbang Depdiknas.

Budimansyah, Dasim, dkk. (2000). Studi Eksperimen Pengembangan Model Pembelajar Berbasis Portofolio di SMU Negeri 8 Bandung. Laporan Hasil Penelitian IKIP Bandung. (2002). Model Pembelajaran dan Penilaian Berbasis Portofolio. Bandung: Penerbit Genesindo.

Budimansyah, Dasim dan Arnie Fajar. (2001). Model Pembelajaran Berbasis Portofolio Kesadaran Hukum masyarakat. Modul 
Pelatihan Proyek Imtag,

Kewarganegaraan, dan Budi pekerti, Direktorat Jendral Pendidikan Dasar dan Menengah, Depdiknas.

Center for Indonesia Civic Education. (1999). Democratic Citizens in a Civic Society : Building Rationales for the 21 Century's Civic Education, Bandung.

Hamalik, Oemar. (2003). Kurikulum dan Pembelajaran. Jakarta: Bumi Aksara

Joyce, Bruce dan Weil, M.E. (!986). Model of Teaching. New York: Mac Millan.

Miller, Jhon P. (2002). Cerdas di Kelas Sekolah Keprribadian. Alih bahasa Abdul Munir Mulkhan. Yogyakarta: Kreasi Wacana.

Mulyasa, Enco. (2002). Kurikulum Berbasis Kompetensi. Bandung: Remaja Rosdakarya.

Edi, Sarwo. (2005). Pengaruh Strategi Pembelajaran dengan Menggunakan Media Gambar dan Kemampuan Awal Terhadap Peningkatan Kemampuan Membaca Aman Dikelompok Bermain : Tesis. Medan Unimed.

Fudyartanto, Ki, RBS. (2002). Psikologi Pendidikan dengan Pendekatan Baru. Yogyakarta : Global Pustaka Utama.

Gagne, RM. (1995). The Condition of Learning and Theory of Instruction, Fourth Edition. New York: New Jersey.

Nawawi, H. (2004). Strategi Belajar Mengajar. Jakarta: UI Press.

Parji. (2002). Strategi Pembelajaran Pendidikan Moral Pada Era Teknologi Imformasi. Jakarta: PTPI dan LPTK.

Rahman, Maman. (2001). Reposisi Reevaluasi dan Revisi Pendidikan Nilai Bagi Generasi Muda Bangsa. Jurnal
Pendidikan dan Kebudayaan, No. 028 Tahun Ke-7. Jakarta: Badan Penelitian dan Pengembangan Depdiknas.

Reugeluth, C.M. (2001). Insrukctional Design Theory and Model. New Jersey: Publisher is Hilisdale.

Rocker, M.J. (1980). Innovative Teaching Strategies. Scotdale: Gorsuch Svarisbrich, Publishing.

Salam, Sofian. (2000). Pembelajaran Model Portofolio. Makasar: Universitas Negeri Makasar.

Sardiman, A.M. (2003). Interaksi dan Motivasi Belajar Mengajar. Jakarta: Raja Grafindo Persada.

Setiawan, Denny. (2003). Praktik Belajar Kewarganegaraan (Bahan Pelatihan).Medan: Depdiknas dan Central For Civil Education, Indonesia.

Shaklee, D. Beverly. (1997). Designing and Using Portofolio. United States of America, Acly \& Bacon - Autacom Company.

Shelbecker, G.e. (1947). Learning Theory Instructional Theory and Psycho Educational Design. New York: MC. Graw Hill Book Co.

Sudjana, S. dkk. (2002). Pendidikan Kewarganegaraan. Jakarta: Gramedia Pustaka Utama.

Tremey, J, Robert. (1991). Portofolio Asseament in the Reading- Writing Classroom. United States of America: Christoper- Gorden, Publishers, Inc.

Yager, E Robert. (1996). STS Sciencel Teknologi/ Societi As Reform In Science Education. New York, United States of America. 